\title{
Differential routing of 'new' nitrogen toward higher trophic levels within the marine food web of the Gulf of Aqaba, Northern Red Sea
}

\author{
N. Aberle - Thomas Hansen - Ruth Boettger-Schnack • \\ Antje Burmeister · Anton F. Post · Ulrich Sommer
}

Received: 3 July 2009/Accepted: 16 September 2009/Published online: 2 October 2009

(C) Springer-Verlag 2009

\begin{abstract}
Mesozooplankton communities in the mesooligotrophic Gulf of Aqaba, Northern Red Sea, were investigated over a 2 years period (2005-2007) with emphasis on the trophodynamic relations among different taxonomic groups ranging from primary consumers to carnivorous predators. Based on stable isotope analyses, we present evidence for a strong contribution of 'new' nitrogen mainly derived from the utilization of aerosol nitrate by unicellular cyanobacteria especially during summer stratification and the propagation of exceptionally low $\delta^{15} \mathrm{~N}$ onto higher trophic levels. In contrast, $\mathrm{N}_{2}$-fixation by diazotrophs seemed to play a minor role, while the utilization of deep water nitrate by cyanobacteria and eukaryotic algae might be of importance during winter mixing. Based on ${ }^{15} \mathrm{~N}$ enrichment of consumers, clear differences between exclusively herbivorous organisms (doliolids, appendicularians, pteropods) and those with omnivorous feeding modes were detected. The category of omnivores comprised a large variety of taxons ranging from small meroplanktonic larvae to non-calanoid copepods (harpacticoids, cyclopoids and poecilostomatoids) that together form a
\end{abstract}

Communicated by $\mathrm{X}$. Irigoien.

N. Aberle - T. Hansen - R. Boettger-Schnack - A. Burmeister · U. Sommer

IFM-GEOMAR Leibniz Institute of Marine Sciences, Kiel, Germany

N. Aberle $(\square)$

Biologische Anstalt Helgoland, Stiftung Alfred-Wegener Institute for Polar and Marine Research, Helgoland, Germany e-mail: Nicole.Aberle-Malzahn@awi.de

A. F. Post

Interuniversity Institute for Marine Sciences,

Hebrew University, Eilat, Israel diverse and complex community with overlapping feeding modes. In addition, distinct seasonality patterns in $\delta^{15} \mathrm{~N}$ of copepods were found showing elevated trophic positions during periods of winter mixing, which were most pronounced for non-calanoid copepods. In general, feeding modes of omnivores appeared rather unselective, and relative contributions of heterotrophic protists and degraded material to the diets of non-calanoid copepods are discussed. At elevated trophic positions, four groups of carnivore predators were identified, while calanoid copepods and meroplanktonic predators showing lowest ${ }^{15} \mathrm{~N}$ enrichment within the carnivores. The direct link between 'new' nitrogen utilization by primary producers and the ${ }^{15} \mathrm{~N}$ enrichment of consumers in the planktonic food web of the Gulf of Aqaba emphasizes the significant contribution of 'new' nitrogen to the nitrogen budget and ecosystem functions in subtropical and tropical oligotrophic oceans.

\section{Introduction}

Traditionally, filter-feeding copepods have been considered to graze predominantly on large phytoplankton. However, there is increasing evidence that omnivory plays an important role and that a substantial fraction of ciliates and heterotrophic nanoflagellates (HNF) contribute to the diet of copepods (Kleppel 1993; Calbet and Landry 1999; Sommer et al. 2002). In oligotrophic marine waters like those found in the Red Sea primary producers show a predominance of pico- and nanophytoplankton (Lindell and Post 1995; Al-Najjar et al. 2007). In such waters it is considered unlikely that copepods serve as primary consumers preying upon small phytoplankton fractions. In fact, it is hypothesized that copepods and most other mesozooplankters are placed at the third or even the fourth trophic 
level, while microzooplankton e.g. ciliates and HNF form the trophic link between phytoplankton and mesozooplankton (Kleppel et al. 1988; Calbet and Landry 1999; Sommer et al. 2002; Berninger and Wickham 2005). In addition, filter-feeding zooplankton e.g. tunicates, pteropods, ostracods or meroplanktonic larvae with the ability to feed on particles $<2 \mu \mathrm{m}$ are considered as true herbivores that constitute the second trophic level (Sommer et al. 2002).

The objective of the present study was to reconstruct the planktonic food web in the surface layers of the Gulf of Aqaba (GoA), from the base of the food web up to mesoand macrozooplankters (including meroplanktonic larvae and gelatinous zooplankton), during a 2-year sampling campaign. Based on stable isotope analyses, the $\delta^{15} \mathrm{~N}$ enrichment of consumers relative to the baseline value obtained for exclusive herbivores was calculated in order to define seasonal patterns and shifts in trophic positions of zooplankters over the annual cycle of deep mixing (mesotrophic conditions) and stable stratification (oligotrophic conditions). Special emphasis was placed on the trophic position of abundant calanoid, cyclopoid, poecilostomatoid and harpacticoid copepod species. We tested the hypothesis that copepods in the GoA are omnivores rather than herbivores and that small picophytoplankton fractions serve as the primary food source of filter-feeding zooplankton at the base of the food web.

Furthermore, exceptionally low $\delta^{15} \mathrm{~N}$ of particulate organic matter (POM) and zooplankton fractions have been reported from subtropical and tropical oceans (Montoya et al. 2002; McClelland et al. 2003), pointing at an overall importance of 'new' nitrogen sources fueling planktonic food webs in oligotrophic regions. Traditionally, such low $\delta^{15} \mathrm{~N}$ of POM has been attributed to nitrogen fixation by diazotrophs channeling 'new' atmospheric nitrogen to the euphotic zones (Montoya et al. 2002; McClelland et al. 2003). In the GoA, however, where filamentous and unicellular diazotrophs play only a minor role, it was shown that the input of aerosol nitrate to surface waters represents an important source of 'new' nitrogen with potentially strong impacts on the $\mathrm{N}$-fluxes in this system (Wankel et al. 2009). Therefore, a further objective of our study was to assess the role of 'new' nitrogen fueling the planktonic food web in the GoA via nitrate utilization instead of $\mathrm{N}_{2}$-fixation.

\section{Materials and methods}

Field sampling

Meso- and macrozooplankton for stable isotope analysis was sampled from May 2005 to June 2007 at Station A $\left(29^{\circ} 18^{\prime} \mathrm{N}\right.$ and $34^{\circ} 56^{\prime} \mathrm{E}$, water depth $600-700 \mathrm{~m}$, GoA, Red Sea). The first sampling took place right at the interface between winter mixing and summer stratification (May 2005). The sampling campaign was continued and intensified during the transition from summer stratification to winter mixing in autumn 2005 by taking qualitative zooplankton samples every 2 nd or 3rd day from 21 September to 11 October 2005 . Thereafter, the sampling campaign was continued at nearly monthly intervals.

For meso- and macrozooplankton sampling, oblique hauls $(0-10 \mathrm{~m})$ with $100 \mu \mathrm{m}$ mesh plankton net were towed for $10 \mathrm{~min}$ from a research vessel. Zooplankton samples were stored at $17^{\circ} \mathrm{C}$ for $1-3 \mathrm{~h}$ prior to live sorting in the laboratory. From November 2005 onward, monthly zooplankton samples were fixed with ethanol and thereafter sorted. In the laboratory samples were sieved over a $100-\mu \mathrm{m}$ mesh, transferred to Petri dishes with filtered seawater, and the zooplankton specimens were handpicked under a dissecting microscope. The organisms were initially differentiated as morphotypes or higher taxonomic levels and subsequently sorted into tin caps (HEKAtech). Reference material of each morphotype was preserved in ethanol and/or formaldehyde for a subsequent, more detailed taxonomic identification to genus or species level. The number of specimens sorted per cap corresponded to a total weight of approximately $80 \mu \mathrm{g} \mathrm{C}$ and $10 \mu \mathrm{g} \mathrm{N}$. Immediately after sorting, zooplankton samples were dried at $60^{\circ} \mathrm{C}$ for at least $24 \mathrm{~h}$ and stored in a desiccator until further analyses of stable isotope composition $\left(\delta^{15} \mathrm{~N}\right)$. In the present paper, the taxonomic classification of copepods into the pelagic orders Calanoida, Cyclopoida, Poecilostomatoida and Harpacticoida follows the scheme of Huys and Boxshall (1991). Recently, the ordinal classification of the Copepoda has changed, and the Poecilostomatoida, which include the pelagic families Oncaeidae, Corycaeidae and Sapphirinidae, are no longer regarded as a separate order but are included in the Cyclopoida (see arguments given by Boxshall and Halsey 2004). This course of action has not universally been accepted yet (Ho et al. 2006). Due to the apparently different ecological role, the poecilostomatoidan families play in the copepod community as a specific functional group (see review by Boettger-Schnack et al. 2004), the earlier defined order of Poecilostomatoida has been kept in the present study.

Stable isotope analysis

Sample weights for stable isotope analysis of individual taxa of zooplankton and seston were 12-48 $\mu \mathrm{g} \mathrm{C}$ (maximum: $80 \mu \mathrm{g} \mathrm{C}$ ) and 2-8 $\mu \mathrm{g} \mathrm{N}$ (maximum: $10 \mu \mathrm{g} \mathrm{N}$ ), respectively. Stable isotope analysis of the samples was performed by using a high sensitive elemental analyzer 
(CE INSTRUMENTS EA1110) connected to a stable isotope ratio mass spectrometer (Thermofinnigan Delta ${ }^{\text {Plus }}$ Advantage) (Hansen and Sommer 2007). During measurements, the mass spectrometer determines the ${ }^{15} \mathrm{~N} /{ }^{14} \mathrm{~N}$ ratio. Isotopic compositions are expressed by the $\delta$ notation, which are parts per thousand deviations from a standard:

$$
\delta \mathrm{X}=\left(R_{\text {sample }} / R_{\text {standard }}-1\right) \times 1,000, \text { where } R=\text { heavy } /
$$
light isotope $(\delta \mathrm{X}>0=$ enriched in heavy isotope, $\delta \mathrm{X}<0=$ depleted in heavy isotope or enriched in light isotope). Isotope measurements were calibrated against international standards (IAEA-N1, IAEA-N2, IAEA-N3) and material from the National Institute of Standards and Technology (NBS22, Graphite). Additionally, the internal laboratory standard acetanilide with $\delta^{15} \mathrm{~N}$ of $-2.56 \% \pm$ 0.53 (standard deviation) was measured after every sixth samples during analysis to control the data quality.

\section{Baseline signatures}

In order to achieve reliable baseline signals over the whole monitoring period, the $\delta^{15} \mathrm{~N}$ of true herbivores (Pteropoda, Doliolida and Appendicularia) was pooled at each date. Baseline values were calculated as the mean of all individuals analysed at each sampling date by giving each individual equal weight.

Trophic ${ }^{15} \mathrm{~N}$ enrichment $\left(\Delta \delta^{15} \mathrm{~N}_{\text {Baseline }}\right)$

Trophic ${ }^{15} \mathrm{~N}$ enrichment is described in terms of the difference in delta $(\delta)$ values between food source $(\mathrm{A})$ and consumer (B) using the $\Delta$ notation, where $\Delta=\delta_{\mathrm{B}}-\delta_{\mathrm{A}}$. A positive $\Delta$ value indicates a relatively higher concentration of heavy nitrogen isotope in B. In this study, the trophic ${ }^{15} \mathrm{~N}$ enrichment of consumers is given relative to the $\delta^{15} \mathrm{~N}$ of baseline organisms indicating their trophic position ( $\left.\Delta \delta^{15} \mathrm{~N}_{\text {Baseline }}\right)$. In general, a $2.2 \%$ increase in ${ }^{15} \mathrm{~N}$ is regarded as significant enrichment at each trophic level for invertebrates (Fry 2006).

\section{Definition of seasons}

Based on chlorophyll $a$ data from a routine monitoring campaign conducted by the Interuniversity Institute for Marine Sciences (Hebrew University, Eilat, Israel) on monthly intervals at the sea surface at Station A $\left(29^{\circ} 18^{\prime} \mathrm{N}\right.$ and $34^{\circ} 56^{\prime} \mathrm{E}$ ) as well as on biotic and abiotic parameters (temperature, oxygen and chlorophyll $a$ ) obtained from the literature (Claessens et al. 2008), two distinct seasons for the northern GoA could be defined: (1) summer stratification (period from May to September) and (2) winter mixing (period from October to April).

\section{Zooplankton categories}

Zooplankton sampled at Station A during the whole sampling campaign was grouped into different categories related to their observed trophic position revealed from $\delta^{15} \mathrm{~N}$ analysis. Overall three categories of consumers were detected consisting of (1) herbivores, (2) omnivores and (3) carnivores. The categories were split into subcategories that were as follows: for category (1), Baseline (those organisms a priori defined as real herbivores: Appendicularia, Doliolidae and Pteropoda), for category (2), PlanktonBase (Cladocera, Pluteus larvae, Gastropoda and Turbellaria), Harpacticoida, Cyclopoida, Poecilostomatoida and for category (3), Calanoida, MeroplanktonPred (predatory meroplanktonic larvae: polychaet larvae, fish larvae and zoea larvae), Higher Crustacea (adult crustaceans: Amphipoda, Euphausiacea and Mysidacea) and GelatinPred (predatory gelatinous zooplankton: Chaetognatha, Siphonophora and Hydromedusae).

Statistical analysis

To test for significant differences in $\delta^{15} \mathrm{~N}$ of baseline organism (Pteropoda, Doliolida and Appendicularia) over the 2 years monitoring period, a two-factorial ANOVA with the dependent variable $\delta^{15} \mathrm{~N}$ and the factors Date (F1) and Taxa (F2) was performed. Differences in the mean $\delta^{15} \mathrm{~N}$ of the different orders of copepods and differences within one copepod order in relation to stratification or mixing were tested by two-way analysis of variance (ANOVA) with the independent variable $\delta^{15} \mathrm{~N}$ and the factors Category (F1) and Mixed vs. Stratified (F2). We further used a one-way ANOVA to test for differences in $\Delta \delta^{15} \mathrm{~N}$ of zooplankton categories where we used $\Delta \delta^{15} \mathrm{~N}$ as dependent variable and Category as factor. All statistical tests were performed using the Statistica 7.1 software package.

\section{Results}

$\delta^{15} \mathrm{~N}$ of the baseline

No significant difference between the $\delta^{15} \mathrm{~N}$ of Pteropoda, Doliolida and Appendicularia at each sampling date could be found, thus allowing the calculation of mean baseline signals by pooling the $\delta^{15} \mathrm{~N}$ of single-taxon measurements. Mean $\delta^{15} \mathrm{~N}$ of the baseline varied over the whole monitoring period between -0.7 (08 November 2005) and 1.8\%o (11 October 2005) (Figs. 2, 4). Strong baseline shifts were observed with the onset of mixing in October 2005 and November 2006 when within days an enrichment of almost $2 \%$ in $\delta^{15} \mathrm{~N}$ was observed. Smaller shifts of $0.5-1 \%$ in 
$\delta^{15} \mathrm{~N}$ in the baseline were observed in January 2006 and April 2007.

Trophic enrichment of zooplankton categories

Mean $\Delta \delta^{15} \mathrm{~N}_{\text {Baseline }}$ of the zooplankton showed significant differences between categories $(P<0.05)$ (Fig. 1). Within the category of omnivores (2), no differences were detected between the subcategories (PlanktonBase, Harpacticoida, Poecilostomatoida and Cyclopoida). However, trophic enrichment of omnivores was significantly lower when compared to all carnivore subcategories $(3)(P<0.05)$. The category of carnivores (3) showed significant differences between subcategories with Calanoida and MeroplanktonPred showing significantly lower $\Delta \delta^{15} \mathrm{~N}_{\text {Baseline }}$ than Higher Crustacea and GelatinPred $(P<0.05)$.

$\delta^{15} \mathrm{~N}$ of taxonomic groups

\section{Macrozooplankton}

The macrozooplankton showed a high variability in $\delta^{15} \mathrm{~N}$, and no distinct seasonal patterns for any of the macrozooplankton groups could be observed (Fig. 2a). During the transition phase between stratification and mixing in autumn 2005, the macrozooplankton was dominated by amphipods, gastropods and turbellarians, while in autumn 2006 almost no macrozooplankters were sampled. From December 2005 to July 2006 adult planktonic polychaetes were found frequently in the samples showing a high variability in $\delta^{15} \mathrm{~N}(0.8-4.5 \%$ in January and February 2006, respectively). In addition, single euphausiaceans were collected at some occasions during the sampling

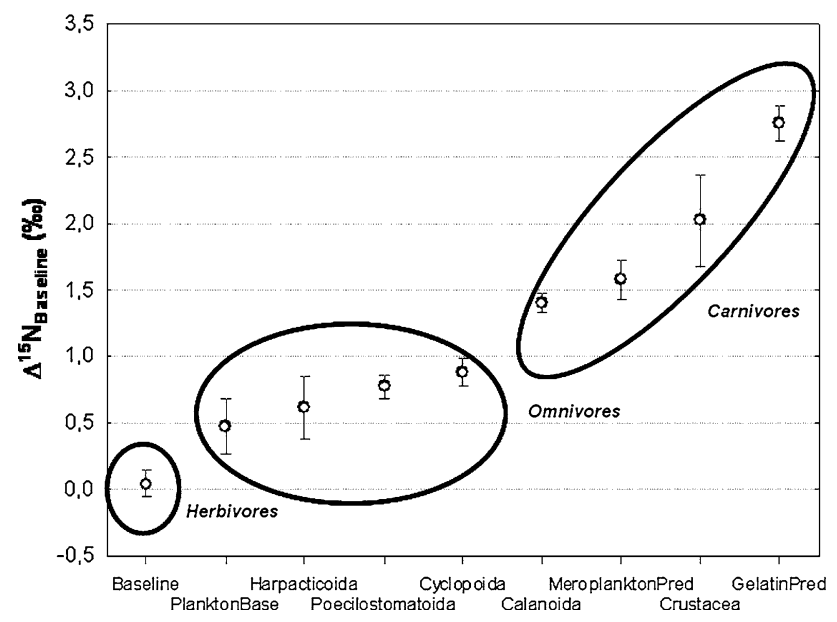

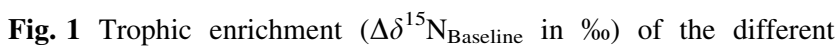
zooplankton categories found over the whole study period from 2005 to 2007. Circles indicate the categories (Herbivores, Omnivores and Carnivores) and the different subcategories within the mesozooplankton accounted for. Error bars \pm 1 standard error period showing a broad range of $\delta^{15} \mathrm{~N}$ values $(0.6-4.0 \%$ in June 2006 and October 2005, respectively). Gastropods and turbellarians showed in general only slight enrichments relative to the baseline.

\section{Meroplankton}

Meroplanktonic larvae and fish eggs showed a broad range in $\delta^{15} \mathrm{~N}$ with pluteus larvae being in general depleted and fish eggs being highly enriched in heavy nitrogen relative to the baseline (Fig. 2b). With the onset of mixing in autumn, zoea larvae showed a strong increase in $\delta^{15} \mathrm{~N}$, while they showed only slight enrichment during the rest of the year. Apart from the mixing period in autumn, $\delta^{15} \mathrm{~N}$ of pluteus larvae remained relatively constant during winter, spring and summer showing depletion in $\delta^{15} \mathrm{~N}$ relative to the baseline. Fish and polychaete larvae were sampled only sporadically; $\delta^{15} \mathrm{~N}$ of fish larvae ranged between 2.4 and 8.2\% (in March and December 2006, respectively) and polychaete larvae between -0.6 and $4.5 \%$ (in November 2006 and May 2007, respectively). Fish eggs were sampled twice during the onset of mixing (October 2005) showing high $\delta^{15} \mathrm{~N}$ of 8.6 and $9.6 \%$.

\section{Gelatinous zooplankton}

The $\delta^{15} \mathrm{~N}$ of gelatinous zooplankton showed a broad range in $\delta^{15} \mathrm{~N}$ with the lowest values for appendicularians and doliolids (corresponding to their role as baseline organisms) and the highest enrichment detected for hydromedusae with the onset of mixing in autumn 2005 (Fig. 2c). However, the $\delta^{15} \mathrm{~N}$ of hydromedusae was by far lower throughout the rest of the year and showed less enrichment compared to chaetognaths (mainly Sagitta spp.). The trophic enrichment of chaetognaths remained relatively high and constant throughout the year $\left(\delta^{15} \mathrm{~N}\right.$ mainly between 3 and $4 \%$ ); however, a drop in $\delta^{15} \mathrm{~N}$ of around $1-2 \%$ occurred at three occasions (October 2005, February and July 2006). $\delta^{15} \mathrm{~N}$ of siphonophores showed a high variability with a low enrichment or depletion relative to the baseline in winter/spring and a strong enrichment in summer and autumn.

$\delta^{15} \mathrm{~N}$ of copepods during stratification and mixing

While the $\delta^{15} \mathrm{~N}$ of all other taxonomic groups showed no seasonal patterns, the $\delta^{15} \mathrm{~N}$ of copepods (Calanoida, Poecilostomatoida, Cyclopoida and Harpacticoida) showed significant seasonal differences over the whole study period $(P<0.05)$ (Fig. 3). A significant effect of the thermal structure of the water column on the $\delta^{15} \mathrm{~N}$ of the four orders of copepods was detected $(P<0.05)$ showing higher $\delta^{15} \mathrm{~N}$ of copepods during periods of winter mixing and lower 

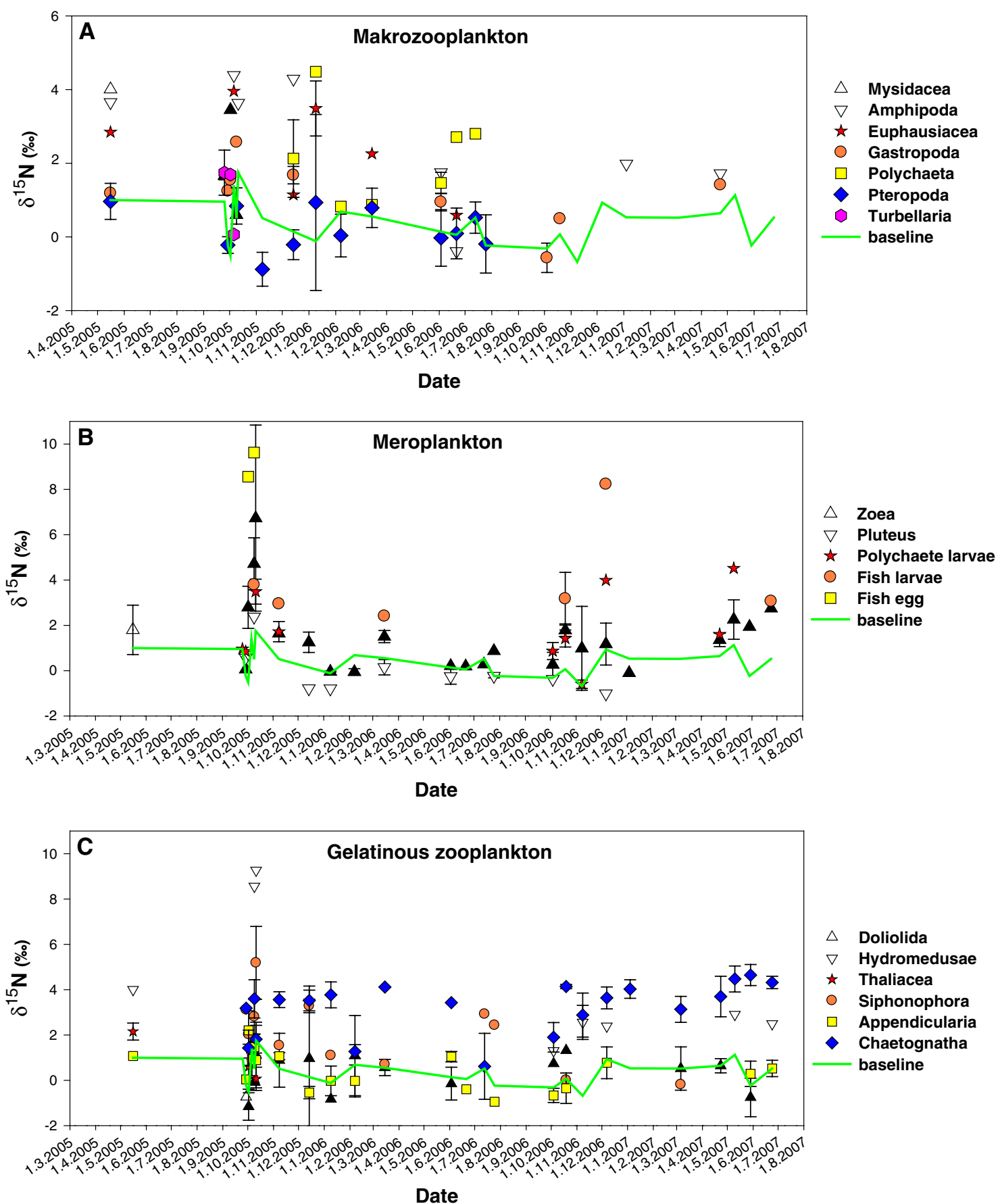

Fig. $2 \delta^{15} \mathrm{~N}$ (in \%o) of the three different zooplankton groups in the GoA, Eilat, Israel: a Makrozooplankton, b Meroplankton and c Gelatinous zooplankton. Error bars \pm 1 standard deviation

$\delta^{15} \mathrm{~N}$ during summer stratification. Calanoids showed the highest $\delta^{15} \mathrm{~N}$ reaching values of $1.73( \pm 0.08)$ during mixing periods and $1.56( \pm 0.13)$ during stratification. Intermediate $\delta^{15} \mathrm{~N}$ values were detected for poecilostomatoid (mixing: $1.39 \pm 0.10$; stratified: $0.51 \pm 0.16$ ) and cyclopoid copepods (mixing: $1.31 \pm 0.12$; stratified: $0.85 \pm$
0.17 ), while only a moderate ${ }^{15} \mathrm{~N}$ enrichment relative to the baseline was detected for harpacticoids (mixing: $1.09 \pm 0.30$; stratified: $0.37 \pm 0.36$ ). Overall, the differences in $\delta^{15} \mathrm{~N}$ between seasons were most pronounced for poecilostomatoids, cyclopoids and harpacticoids showing $\delta^{15} \mathrm{~N}$ of $<1 \%$ during summer stratification. 


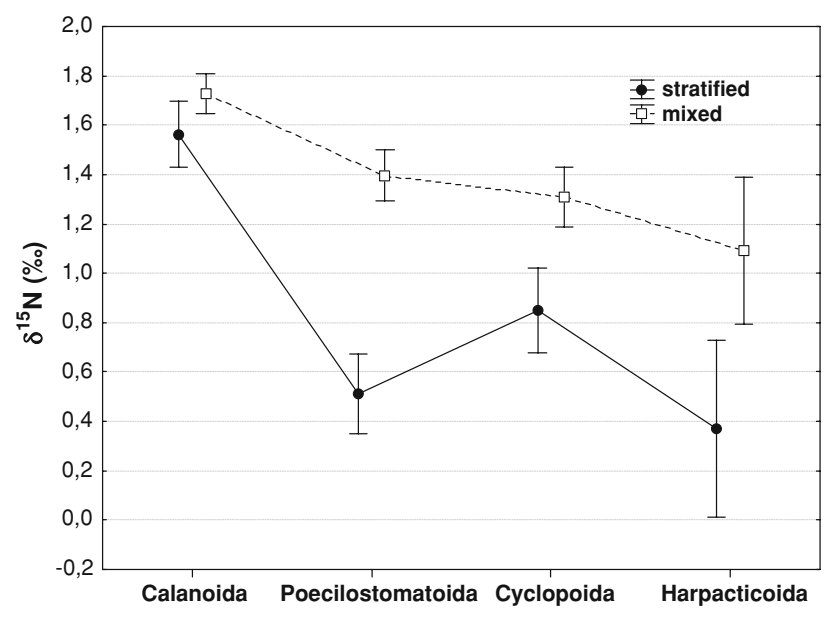

Fig. $3 \delta^{15} \mathrm{~N}$ (in \%o) of the different copepod groups (Calanoida, Poecilostomatoida, Cyclopoida and Harpacticoida) during periods of summer stratification (stratified) and winter mixing (mixed). Filled black circles indicate $\delta^{15} \mathrm{~N}$ of copepods during stratification, white squares indicate $\delta^{15} \mathrm{~N}$ of copepods during mixing. Error bars \pm 1 standard error

$\delta^{15} \mathrm{~N}$ of copepods

\section{Calanoida}

Of the six species of calanoid copepods identified during the present study Clausocalanus furcatus, Centropages elongatus and Acartia sp. occurred year round, while three other species (Calocalanus spp., Mecynocera clausi and Paracalanus sp.) occurred only temporarily (Fig. 4a). C. furcatus and Acartia sp. showed the highest $\delta^{15} \mathrm{~N}$ variations ranging in mean between $0.01 \%$ in March 2007 and $6.8 \%$ in October 2005 for $C$. furcatus and between 1.2\%o in March 2007 and 6.8\%o in October 2005 for Acartia sp. In general, the calanoids $C$. elongatus (in mean $-2.1 \%$ o in March 2007 and 3.7\%o in October 2005) and Acartia sp. (in mean 1.1\%o in February 2006 and 6.7\%o in October 2005) showed the highest $\delta^{15} \mathrm{~N}$, while for C. furcatus, M. clausi, Calocalanus spp. and Paracalanus sp. lower $\delta^{15} \mathrm{~N}$ was observed, except for the transition from summer stratification to winter mixing where increases in $\delta^{15} \mathrm{~N}$ could be observed.

\section{Poecilostomatoida and Cyclopoida}

Overall five species of cyclopoids and six species of poecilostomatoid copepods were identified in our samples from in the uppermost surface layer of the GoA whereof only the poecilostomatoid Farranula carinata occurred year round (Fig. $4 \mathrm{~b}$ ). $\delta^{15} \mathrm{~N}$ of $F$. carinata fluctuated throughout the year showing in general higher $\delta^{15} \mathrm{~N}(>1 \%$ ) during winter mixing and lower values $(<1 \%$ ) during summer stratification. In contrast, Onychocorycaeus sp. was only slightly enriched in ${ }^{15} \mathrm{~N}$ relative to the baseline showing $\delta^{15} \mathrm{~N}<1 \%$, while Corycaeus speciosus showed in general a stronger enrichment relative to the baseline with $\delta^{15} \mathrm{~N}$ between 1 and 2\%. Within the Oithonidae (Cyclopoida), the highest trophic enrichment ( $>1 \%$ ) of Oithona sp. was detected during the onset of winter mixing, while during summer $\delta^{15} \mathrm{~N}$ was low $(<1 \%$ ). Only slight fluctuations in $\delta^{15} \mathrm{~N}$ were observed for Oithona tenuis, Oithona rigida and Oithona plumifera (mainly between 0.5 and $2 \%$ ). In general, the $\delta^{15} \mathrm{~N}$ of cyclopoids and poecilostomatoids were within similar ranges, while the lowest $\delta^{15} \mathrm{~N}$ could be observed for Oithona simplex and Oncaea spp.

\section{Harpacticoida}

The only harpacticoid sampled in the uppermost surface layer of the GoA was Microsetella norvegica (Fig. 4c). The $\delta^{15} \mathrm{~N}$ of $M$. norvegica was close to the baseline; however, slight enrichments relative to the baseline were found. Only during the onset of winter mixing, the $\delta^{15} \mathrm{~N}$ of $M$. norvegica increased temporarily showing a shift of almost one trophic level $(2.2 \%)$ relative to the baseline.

\section{Discussion}

It must be emphasized that the present study focused on trophodynamic interactions in the surface layers and thus does not necessarily reflect the complexity of interactions for the entire food web of the GoA. Important carnivores ascending to the surface layer during the night like Pleuromamma sp. are thus underrepresented. The emphasis was to study the trophic position of zooplankters with a high taxonomic resolution irrespective of their abundance, diurnal migration or seasonal distribution.

\section{Seasonal variability of the baseline}

In this study, the mean $\delta^{15} \mathrm{~N}$ of Pteropoda, Doliolida and Appendicularia served as baseline since filter-feeding zooplankters are expected to reflect direct changes in the primary source of production (Post 2002; Matthews and Mazumder 2003). The isolation of pure primary producer samples from the plankton is however limited since filtration results in bulk seston samples containing a mixture of phytoplankton, mixo- and heterotrophic flagellates, ciliates, bacteria and detritus, each with different trophic positions and isotope signals. Although using seston as baseline would be rather simple, this approach has substantial shortcomings since mesozooplankers feed selectively on specific seston groups (e.g. phytoplankton or heterotrophic protists), and using seston would thus introduce errors when assessing trophic positions of mesozooplankters. 


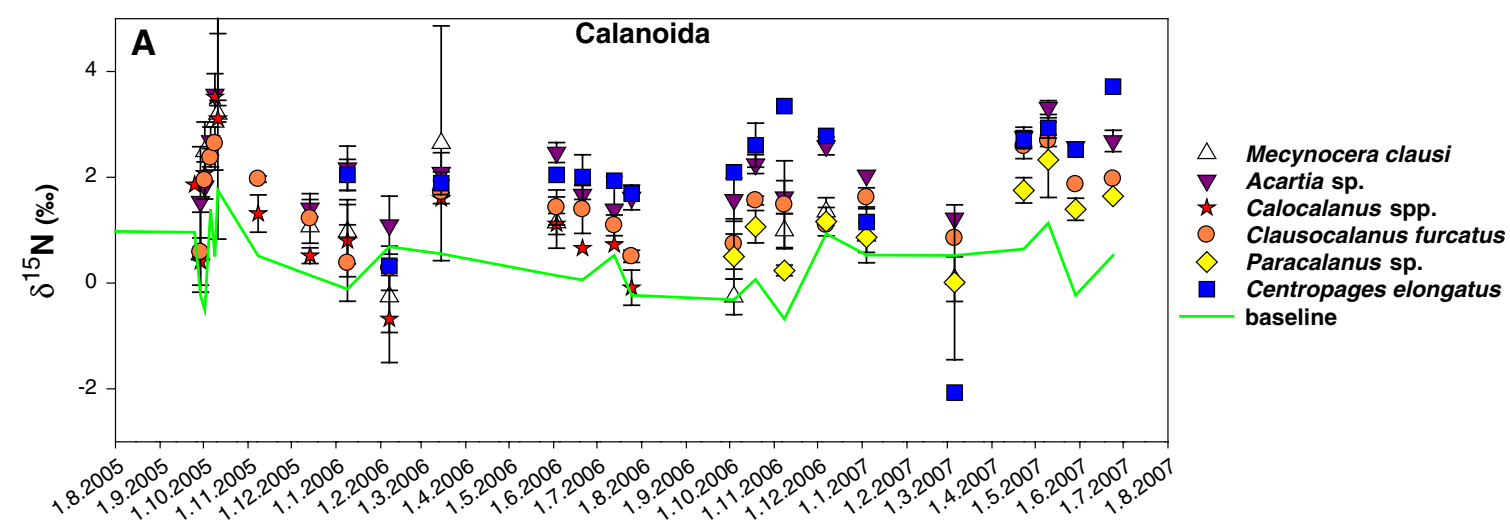

\section{Date}
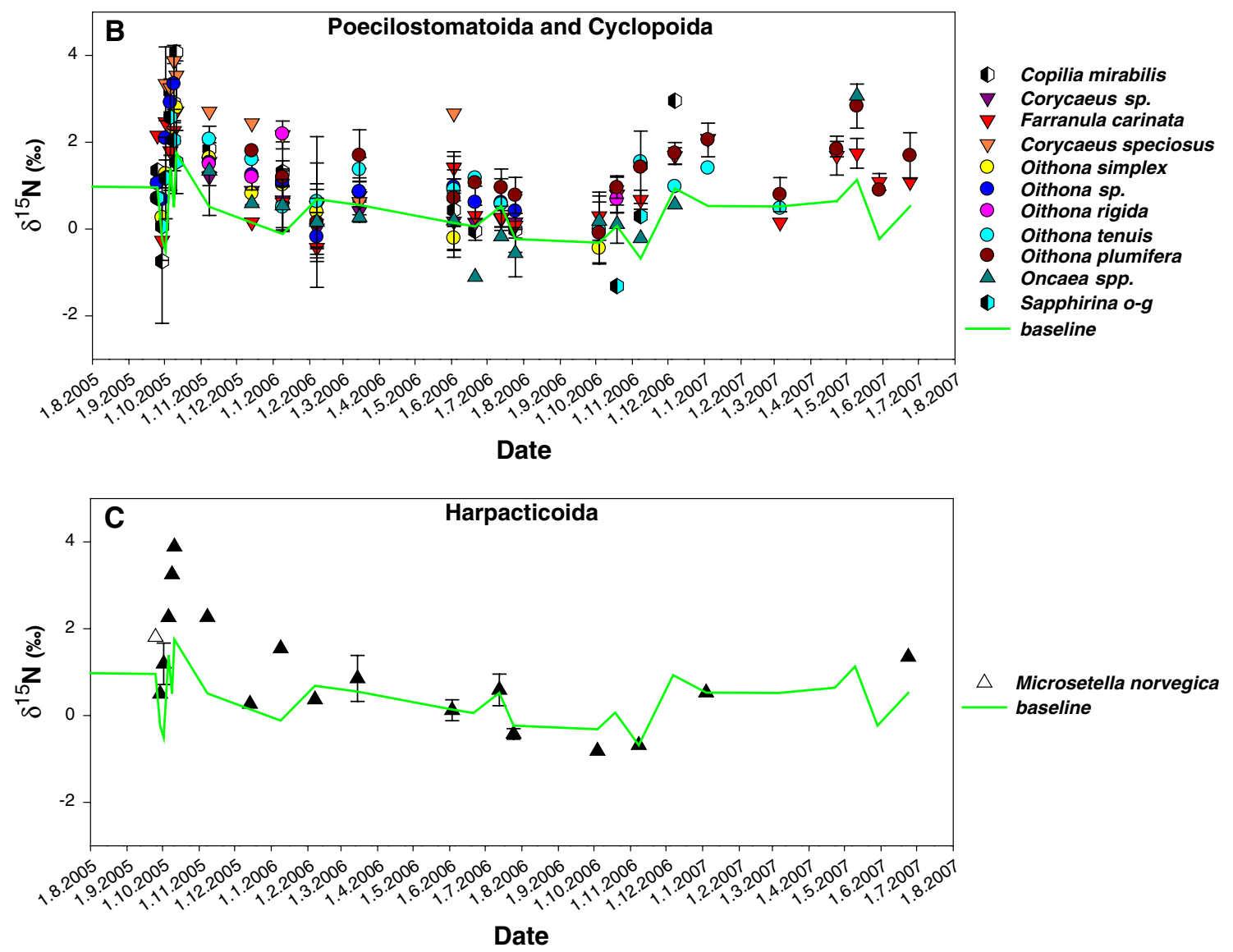

Fig. $4 \delta^{15} \mathrm{~N}$ (in \%o) of the four different orders of copepods sampled in the GoA, Eilat, Israel: a Calanoida, b Poecilostomatoida/ Cyclopoida and c Harpacticoida. Sapphirina o-v stands for Sapphirina ovatolanceolata-gemma. Maximum values in Fig. 4a: Acartia sp.

Therefore, the alternative of using herbivores as a baseline is an accepted approach in stable isotope ecology assuming that the least $\delta^{15} \mathrm{~N}$-enriched species represent the closest possible approximation to trophic level 2 (pure herbivores). This approach has been previously used e.g. for filterfeeding cladocerans (Matthews and Mazumder 2003), filter-feeding mussels and surface-grazing snails (Post
$6.68 \% \pm 1.96$ (date: 11.10.2005) and Clausocalanus furcatus $6.77 \%$ o 3.32 (date: 11.10 .2005 ); Fig. 4b: Oithona sp. 6.88\%o (date: 11.10.2005). Error bars \pm 1 standard deviation

2002). Another advantage of using herbivores as baseline is that primary consumers provide time-integrated values and buffer high inter- and intra-specific variations in stable isotope signatures of primary producers resulting from species-specific differences in isotope fractionation and variable abiotic conditions (e.g. nutrient availabiliy) (Aberle and Malzahn 2007). 
Overall, the mean $\delta^{15} \mathrm{~N}$ of baseline organisms analysed in the present study was very low $(-0.7-1.8 \%$ ). In oligotrophic regions such low $\delta^{15} \mathrm{~N}$ has traditionally been attributed to nitrogen fixation by diazotrophs channeling 'new' atmospheric nitrogen to the euphotic zones (Montoya et al. 2002; McClelland et al. 2003). The filamentous cyanobacterium Trichodesmium spp. was considered as the main source of 'new' nitrogen in surface waters (Montoya et al. 2002). In surface waters of the northern GoA, however, only a seasonal occurrence of Trichodesmium spp. during early summer or late autumn is reported (Kimor and Golandsky 1977; Gordon et al. 1994; Post et al. 2002), while it is considered to play a minor role throughout the rest of the year (Post et al. 2002). In addition, a previous study on the role of Trichodesmium spp. as food source for zooplankters showed that Trichodesmium spp.-specific fatty acids were found predominately in association with Macrosetella gracilis, the sole copepod grazing on Trichodesmium spp. (Post et al. 2002). However, this copepod species was not sampled during the present study. Therefore, it seems unlikely that $\mathrm{N}_{2}$-fixation by Trichodesmium spp. provides the most important source of 'new' nitrogen entering surface waters in the northern GoA, while its role in subsurface waters might be underestimated (Foster et al. 2009).

But there is increasing evidence that unicellular diazotrophs (e.g. cyanobacteria species of the genus Crocosphaera and Cyanothece and the so-called UCYN-A group) play a major role as $\mathrm{N}_{2}$-fixers in oligotrophic oceans (Zehr et al. 2001; Montoya et al. 2004; Zehr et al. 2008; Foster et al. 2009). However, Foster et al. (2009) reported on constant but low $\mathrm{N}_{2}$-fixation rates in the GoA that can most likely be attributed to the 'UCYN-A' cyanobacteria group and the unicellular diazotroph Cyanothece sp. (Mackey et al. 2007). Therefore, a certain proportion of $\mathrm{N}$-input at the base of the food web in the GoA might derive from nitrogen fixation by unicellular diazotrophs. During summer stratification, however, the dominant primary producers in surface waters of the GoA are cyanobacteria of the genus Synechococcus and Prochlorococcus (Lindell and Post 1995; Claessens et al. 2008). With the onset of winter mixing, the abundance of eukaryotic algae increases, and both Synechococcus and eukaryotic algae remain abundant during periods of winter mixing. Synechococcus and Prochlorococcus are considered as non-diazotrophs as they lack nif genes required for $\mathrm{N}_{2}$-fixation (Kettler et al. 2007; Dufresne et al. 2008; Scanlan et al. 2009). It seems thus unlikely that the low $\delta^{15} \mathrm{~N}$ of baseline organisms throughout the year in the present study is predominantly related to an input of 'new' nitrogen to the uppermost surface layer via diazotrophic cyanobacteria.

A recent study by Bauersachs et al. (2009) demonstrates that $\mathrm{NO}_{3}$-assimilating cyanobacteria show low $\delta^{15} \mathrm{~N}$ levels similar to those found in diazotrophs. This finding contrasts the well-established argument that low $\delta^{15} \mathrm{~N}$ of POM results from dinitrogen fixation in oligotrophic oceans alone. Our results on low $\delta^{15} \mathrm{~N}$ coupled with the minor contribution of $\mathrm{N}_{2}$-fixers give further evidence that nitrateutilizing cyanobacteria form the primary energy source at the base of the food web in the GoA. While deep water nitrate becomes available during periods of deep mixing events only and has on average a $\delta^{15} \mathrm{~N}$ of ca. $5 \%$ (Casciotti et al. 2008), the importance of aerosol nitrate introduced to surface waters of the GoA was stressed recently showing that the $\delta^{15} \mathrm{~N}$ of aerosol $\mathrm{NO}_{3}$ was on average $-2.6 \%$, thus contributing significantly to low $\delta^{15} \mathrm{~N}$ nitrogen sources in the GoA (Wankel et al. 2009). In addition, Chen et al. (2007) estimated that aerosol nitrate supplies ca. $35 \%$ of the soluble inorganic nitrogen to the euphotic zone during stratification assuming that a high proportion of the new production is fueled by this $\mathrm{N}$-source during summer in the GoA. Thus, aerosol nitrate might represent an important source of 'new' nitrogen with a low $\delta^{15} \mathrm{~N}_{\mathrm{NO} 3}$. This leads us to the assumption that aerosol-derived nitrate utilized by the dominant cyanobacteria Synechococcus and Prochlorococcus might be a significant source of 'new' nitrogen in the GoA during summer stratification, while utilization of deep water nitrate plays a role mainly during winter mixing.

Seasonal changes in the baseline showed a difference of $2.5 \%$ between minimum and maximum baseline $\delta^{15} \mathrm{~N}$, which were most pronounced at the onset of winter mixing. Shifts in the mean $\delta^{15} \mathrm{~N}$ of baseline organisms could be related to changes either in the $\delta^{15} \mathrm{~N}$ of phytoplankton as a result of changing nitrogen sources used (the use of 'new' vs. regenerated nitrogen as discussed earlier in this section) or in the phytoplankton spectrum at the base of the food web (e.g. a switch from cyanobacteria to eukaryotic algae during summer-winter transition) as different taxonomic groups of algae differ in their $\delta^{15} \mathrm{~N}$ (Aberle and Malzahn 2007). In addition, elevated $\delta^{15} \mathrm{~N}$ could be related to a shift from herbivore- to omnivore-feeding modes with increasing contributions of heterotrophic protists to the diets of consumers (Agurto 2007). This is supported by findings of Claessens et al. (2008) who reported on increases in ciliate abundance in the GoA during periods of transition. It can thus be speculated that changes in the phytoplankton spectrum as well as increasing proportion of heterotrophic protists during summer-winter transition contributed to a shift in $\delta^{15} \mathrm{~N}$ of baseline organisms.

Inter-specific differences in trophic enrichment of consumers

The low $\delta^{15} \mathrm{~N}$ of consumers in our study mirror the low baseline $\delta^{15} \mathrm{~N}$ and the depleted nitrogen sources used 
during primary production. This is in line with studies from the oligotrophic North Atlantic where similarly low values for zooplankton and particulate organic matter were detected (Montoya et al. 2002; McClelland et al. 2003). Originally, it was assumed that photosynthesis in oligotrophic oceans was primarily supported by upwelled nitrate from deeper waters. More recent studies, however, stress the overall importance of $\mathrm{N}_{2}$-fixation (Montoya et al. 2004; Webb et al. 2009) as well as aerosol nitrate (Wankel et al. 2009) being major sources of 'new' nitrogen in tropical and subtropical oligotrophic oceans. As mentioned earlier, the dominance of non-diazotrophs in the GoA and the clear propagation of the depleted nitrogen signal onto higher trophic levels give evidence for a predominance of aerosol nitrate utilization by primary producers.

\section{Copepods}

The copepods analyzed during our study represent the dominant taxonomic groups of copepods usually found in the northern GoA (Sommer et al. 2002; Cornils et al. 2007a). Distinct differences in trophic enrichment among the four orders of copepods are in line with observations on the copepods' feeding mode based on traditional methods (i.e. gut content analyses, grazing experiments), which stress a higher trophic position of calanoids when compared to cyclopoids, poecilostomatoids and harpacticoids (Calbet et al. 2000; Cornils et al. 2007a).

In our study, Acartia sp. and Centropages elongatus usually showed the highest trophic positions within the calanoids ( $\delta^{15} \mathrm{~N}$ between 2 and 4\%o). Compared to $\delta^{15} \mathrm{~N}$ of Acartia tonsa from Chesapeake Bay (Montoya et al. 1990), the degree of enrichment in Acartia sp. in the GoA is low. However, from the Baltic Sea much lower degrees of $\delta^{15} \mathrm{~N}$ enrichment in Acartia sp. have been reported (Agurto 2007). Overall, the findings from our study are in good correspondence to the study from the Baltic Sea as similar $\delta^{15} \mathrm{~N}$ values for both Acartia sp. and Centropages sp. were reported. These findings point at an omnivore feeding mode of Acartia sp. and Centropages elongatus with some tendency toward carnivory in the GoA.

In contrast, $\delta^{15} \mathrm{~N}$ of the small-sized calanoids Calocalanus spp., Paracalanus sp. and Clausocalanus furcatus $(<1 \mathrm{~mm})$ shows moderate degrees of ${ }^{15} \mathrm{~N}$ enrichment relative to the baseline indicating a lower trophic position within the calanoids but not exclusively herbivore diets. In general, small-sized calanoids are considered as important components especially in tropical and subtropical regions, and despite their high abundances, their ecology remains still poorly investigated. This is mainly due to an inappropriate use of nets with fairly large mesh sizes $(>200 \mu \mathrm{m})$, which cannot catch the smaller species. Thus, $100-\mu \mathrm{m}$ mesh was used in the present study to account for small-sized copepods as the use of nets $<150 \mu \mathrm{m}$ (Turner 2004) or even smaller (Boettger-Schnack et al. 2008) was suggested. Recently, Cornils et al. (2007b) stressed the overall role of Clausocalanidae as omnivores rather than herbivores in the GoA showing that especially heterotrophic protists contributed substantially to the diets of clausocalanoids. This is supported by our $\delta^{15} \mathrm{~N}$ data showing that small-sized calanoids serve predominantly as secondary consumers rather than being primary consumers. Cornils et al. (2007b) reported on $\delta^{15} \mathrm{~N}$ ranges for C. furcatus (0.1-3.5\%) and another clausocalanoid species (1.3-3.6\%o) in autumn 2002, which are close to the ranges of clausocalanoids and other small calanoids observed in the present study. The broad $\delta^{15} \mathrm{~N}$ ranges especially during the onset of winter mixing point at a rather unselective, opportunistic feeding mode of small calanoids in the Northern GoA, a finding that is in line with fatty acid and stable isotope data published by Cornils et al. (2007b).

In contrast to calanoid copepods, the ecological role of cyclopoids, poecilostomatoids and harpacticoids remains still poorly known; however, there is growing evidence that feeding modes of non-calanoids differ considerably from those of calanoids (Calbet et al. 2000).

In general, the poecilostomatoid Oncaeidae are a widespread family in oceanic areas (see reviews by Paffenhoefer 1993; Boettger-Schnack et al. 2001, 2008), which usually occur in association to gelatinous zooplankton (Go et al. 1998). The feeding habits of Oncaeidae, however, remain still unclear since both scraping of particulate organic matter from the cell walls of a host (Go et al. 1998), feeding on particles attached to marine snow (Alldredge 1972) and a parasitic feeding mode by tearing body walls and sucking body fluids are discussed so far (Wickstead 1962). Oncaea spp. in our study (mainly Oncaea venusta, O. clevei and unidentified juveniles) showed $\delta^{15} \mathrm{~N}$ close to or even below the baseline year round, evincing its low trophic position in the Red Sea food web. Therefore, the consumption of body tissues or fluids of gelatinous zooplankters by Oncaea spp. can be ruled out, thus adding another piece to the puzzle of this copepods' feeding mode.

Similar to Oncaea spp., the $\delta^{15} \mathrm{~N}$ of several copepods e.g. the cyclopoid Oithona simplex, the poecilostomatoid Farranula carinata, Sapphirina ovatolanceolata-gemma and Copilia mirabilis as well as the harpacticoid Microsetella norvegica were rather low pointing at overlapping resource use of these copepods. As observed for small Oithonidae (Nakamura and Turner 1997; Calbet et al. 2000), a food particle size of $>2 \mu \mathrm{m}$ contrasting to filterfeeding zooplankton (e.g. tunicates, pteropods, ostracods or meroplanktonic larvae) can be assumed. Similar to small calanoids, the $\delta^{15} \mathrm{~N}$ close to or even below the baseline of cyclopoids evinces that they can be categorized rather as omnivores than as herbivores. Our finding on large 
proportions of omnivore, small-sized copepods in the GoA is supported by Turner (2004) who stressed the overall importance of omnivory as a feeding mode of small-sized copepods in the worlds' oceans.

In addition, it can be speculated that suspended particulate nitrogen (PN) could be a potential food item of small cyclopoids and poecilostomatoids as suspended PN in the euphotic zones is usually depleted in ${ }^{15} \mathrm{~N}$ (showing on average a $\delta^{15} \mathrm{~N}$ of $0.2 \%$, Altabet 1988) relative to ${ }^{15} \mathrm{~N}$ enrichment of sinking PN as a result of bacterial degradation (Mintenbeck et al. 2007). This assumption is supported by the fact that $M$. novegica was found in association with appendicularians, thus contributing to the decomposition of marine snow and, more specifically, of appendicularian houses (Koski et al. 2007). This might point at differences in feeding modes between small-sized calanoid and non-calanoid copepods and the role of noncalanoids as a trophic link between microbial and traditional food webs.

In contrast, the relatively large Oithona plumifera, other Oithonidae like $O$. rigida, O. tenuis and Corycaeidae (mainly Corycaeus speciosus) showed higher $\delta^{15} \mathrm{~N}$ pointing at their overall role as omnivores feeding on a mixture of autotrophs and heterotroph protists with a tendency toward carnivory (e.g. C. speciosus). In part, this is supported by findings of Turner (1986) who reported on high shares of dinoflagellates and ciliates in the fecal pellets of Oithonidae and Corycaeidae; however, indication for carnivory has not been reported in the literature so far. In addition, high $\delta^{15} \mathrm{~N}$ could also result from coprophagy as observed by Gonzalez and Smetacek (1994) for Oithonidae, as fecal pellets are usually enriched in heavy nitrogen $\left({ }^{15} \mathrm{~N}\right)$ relative to autotroph diets leading to elevated $\delta^{15} \mathrm{~N}$ in cophrophagous consumers (Aberle et al. 2005). The broad range in $\delta^{15} \mathrm{~N}$ of Oithonidae and Corycaeidae indicates a rather unselective feeding mode, which might explain their successfulness in oligotrophic environments.

Overall, the stable nitrogen isotope data of Harpacticoida, Cyclopoida, Poecilostomatoida and Calanoida in our study point at an important role of copepods as intermediary consumers. It is likely that their direct connectivity to the microbial food web enhances energy transfer efficiencies onto higher trophic levels resulting in an optimal resource use of food web components in oligotrophic oceans.

\section{Other zooplankton}

The lack of $\delta^{15} \mathrm{~N}$ data from oligotrophic regions limits the comparability with non-copepod zooplankton sampled in other subtropical or tropical oceans. Although there is only little overlap in the species analysed within different studies, some comparisons on higher taxonomic groups can be drawn.
Apart from herbivores, there were several taxa that showed only slight trophic enrichment relative to the baseline thus occupying low consumer levels. Within the category PlanktonBase, the $\delta^{15} \mathrm{~N}$ of salps was low, which is in line with observations from other regions (Montoya et al. 1992; Waite et al. 2007) and with the observed feeding habits of salps using mucus nets to filter fine particles (Bone et al. 2000). To our knowledge, no comparable stable nitrogen data on pluteus larvae, planktonic gastropoda (other than pteropods) and turbellarians from the water column are available. Pluteus larvae are suspension feeders feeding on small-sized particle e.g. phytoplankton cells and detritus (Dominguez et al. 2007). Based on our $\delta^{15} \mathrm{~N}$ data, similar feeding modes can be suggested for free-living planktonic turbellarians and gastropods. Overall, a high number of omnivore zooplankters including copepods seem to share the same trophic position in the GoA making them a highly diverse and complex community with similar feeding modes.

Predatory gelatinous zooplankton (Chaetognatha, Siphonophora and Hydromedusae) occupied the highest trophic position within the zooplankton in the GoA showing a trophic enrichment of about one trophic level relative to omnivores. Chaetognaths of the genus Sagitta spp. are categorized as primary carnivores preying predominately not only on copepods with a preference for Oithonidae, Oncaeidae and Corycaeidae, but also on some calanoid copepods (Kehayias et al. 1996; Giesecke and Gonzalez 2004) making them an important link in the transfer of energy from copepods to higher trophic levels (Terazaki 1998). Compared to other studies, the $\delta^{15} \mathrm{~N}$ of chaetognaths were fairly low (average 4\% year round) as chaetognaths from other marine regions showed higher $\delta^{15} \mathrm{~N}$ of e.g. $6 \%$ in the Gulf Stream region (Montoya et al. 1992), 6.5\% at the Senghor Seamount close to the Cape Verde Islands (Meyer-Claeden 2007) and 7\% in a warm-core eddy in the Leeuwin Current off Western Australia (Waite et al. 2007). In regions, however, where low baseline $\delta^{15} \mathrm{~N}$ occurs, low ${ }^{15} \mathrm{~N}$ enrichment of consumers are an expected phenomenon supported e.g. by low $\delta^{15} \mathrm{~N}$ of chaetognaths in the North Pacific Central Gyre in association with $\mathrm{N}_{2}$-fixation (Mullin et al. 1984). Comparable data on Hydromedusae and Siphonophora are scarce, and the few literature available is often contradictory as e.g. Waite et al. (2007) reported on much lower $\delta^{15} \mathrm{~N}$ for siphonophores (2\%o, warm-core eddy in the Leeuwin Current), while Montoya et al. (1992) reported on mean $\delta^{15} \mathrm{~N}$ for siphonophores of $8.6 \%$ in the Gulf Stream region. The same is true for Hydromedusae that are usually considered to occupy high trophic levels e.g. $\delta^{15} \mathrm{~N}$ of $9-13 \%$ in the Baltic Sea (Agurto 2007) or $8 \%$ in the Gulf Stream region (Montoya et al. 1992). Comparisons must be treated with caution since size ranges especially in hydromedusae differ considerably, and as in most 
predators, the diet of carnivorous zooplankton varies with size, shape, differential movement pattern or escape capability of prey (Saito and Kiorboe 2001).

In addition, several meroplanktonic and crustacean predators were found in the GoA occupying similar trophic positions. Mysids, amphipods and euphausiids showed similar $\delta^{15} \mathrm{~N}$ as chaetognaths stressing their overall role as primary carnivores, which is in line with observations of Waite et al. (2007) and Montoya et al. (1992). Especially during the transition periods from summer stratification to winter mixing polychaete larvae, zoea larvae and fish larvae showed considerable $\delta^{15} \mathrm{~N}$ enrichment pointing at their important role as carnivores in the GoA at specific times of the year.

\section{Seasonal variability in consumers}

Distinct seasonal patterns in $\delta^{15} \mathrm{~N}$ during stratification and mixing were found for copepods. Such temporal changes are usually considered as being the result of changes in dietary composition (e.g. phytoplankton vs. microzooplankton consumption) or due to changes in the nutrient supply at the base of the food web (regenerated vs. new production during stratification and mixing). In the GoA, eukaryotic algae and Synechococccus are the most abundant autotrophs during winter mixing, while Synechococcus and Prochlorococcus dominate during summer (Lindell and Post 1995; Claessens et al. 2008). As reported by Claessens et al. (2008) ciliate communities at the uppermost surface layer in the GoA are dominated by small- to medium-sized oligotrich and litosome ciliate, and no differences between periods of summer stratification and winter mixing were observed. A direct link between elevated $\delta^{15} \mathrm{~N}$ in copepods and increased protist grazing during winter is therefore not given. It seems, however, likely that higher $\delta^{15} \mathrm{~N}$ in copepods are indirectly linked to protist grazing via the consumption of higher shares of ${ }^{15} \mathrm{~N}$-enriched HNFs or eukaryotic algae by protists in winter as opposed to the consumption of ${ }^{15} \mathrm{~N}$-depleted cyanobacteria during summer. In this context litosome ciliates might play a key role as intermediary between primary producers and copepods as their abundance increases with the onset of winter mixing and their occurrence can be linked to eukaryotic algae (Claessens et al. 2008).

Especially during the transition from summer stratification to winter mixing, short-term shifts in the $\delta^{15} \mathrm{~N}$ of all consumers were observed pointing at temporal shifts in feeding preferences or food sources. Similar to the general shifts in $\delta^{15} \mathrm{~N}$ of copepods between the two seasons, the short-term shifts in consumers might be related to higher shares of ciliates in the diets of primary consumers. As reported by Claessens et al. (2008), ciliate abundance increase in surface waters of the GoA during periods of transition, and therefore, higher shares of heterotrophic protists as food sources for secondary consumers are expected. This is supported by the finding that distinct short-term shifts in $\delta^{15} \mathrm{~N}$ were observed mainly for copepods, while most carnivores e.g. chaetognaths remained rather unaffected pointing at a higher degree of omnivory in copepods and more selective feeding modes at higher trophic levels.

Acknowledgments This study was funded by the German-Israeli Foundation for Scientific Research and Development (GIF Grant No.: I-732-54.8/2002). We are grateful to the staff of the Interuniversity Institute for Marine Sciences in Eilat, Israel, and especially Marc Chernichovsky and Roy Holzmann for their helpful support during the field campaign. Special thanks go to Dorit Golan and Sigrid Penno who helped us substantially to organize the field campaign and enabled a pleasant sojourn. Monika Claessens is thanked for her kind support and valuable ideas during the initiation of the field campaign. We are grateful to Arne Malzahn and two anonymous reviewers for their fruitful comments on earlier versions of the manuscript. Thanks are due to Dr. K. Schulz (German Centre for Marine Biodiversity Research) for the identification of calanoid copepod species. Financial support to RBS from the German Science Foundation (SCHN 455/4-1) is gratefully acknowledged.

\section{References}

Aberle N, Malzahn A (2007) Interspecific and nutrient-dependent variations in stable isotope fractionation: experimental studies simulating pelagic multi-trophic systems. Oecologia 154:291303

Aberle N, Hillebrand H, Grey J, Wiltshire KH (2005) Selectivity and competitive interactions between two benthic invertebrate grazers (Asellus aquaticus and Potamopyrgus antipodarum): an experimental study using ${ }^{13} \mathrm{C}$ - and ${ }^{15} \mathrm{~N}$-labelled diatoms. Freshw Biol 50:369-379

Agurto C (2007) Assessing mesozooplankton trophic levels in the Baltic Sea and North Sea: a stable isotope study. Dissertation Thesis, University of Kiel, Germany, pp 135

Alldredge AL (1972) Abondonned larvacean houses: a unique food source in the pelagic environment. Science 177:885-887

Al-Najjar T, Badran MI, Richter C, Meyerhoefer M, Sommer U (2007) Seasonal dynamics of phytoplankton in the Gulf of Aqaba, Red Sea. Hydrobiologia 579:69-83

Altabet MA (1988) Variations in nitrogen isotopic composition between sinking and suspended particles-implications for nitrogen cycling and particle transformation in the open ocean. Deep-Sea Res Part A 35:535-554

Bauersachs T, Schouten S, Compaore J, Wollenzien U, Stal LJ, Damste JSS (2009) Nitrogen isotopic fractionation associated with growth on dinitrogen gas and nitrate by cyanobacteria. Limnol Oceanogr 54:1403-1411

Berninger UG, Wickham S (2005) Response of microbial food web to manipulation of nutrients and grazers in the oligotrophic Gulf of Aqaba and northern Red Sea. Mar Biol 147:1017-1032

Boettger-Schnack R, Hagen W, Schnack-Schiel SB (2001) The microcopepod fauna in the Gulf of Aqaba, northern Red Sea: species diversity and distribution of Oncaeidae (Poecilostomatoida). J Plankton Res 23:1029-1035

Boettger-Schnack R, Lenz J, Weikert H (2004) Are taxonomic details of relevance to ecologists? An example from oncaeid microcopepods of the Red Sea. Mar Biol 144:1127-1140 
Boettger-Schnack R, Schnack D, Hagen W (2008) Microcopepod community structure in the Gulf of Aqaba and northern Red Sea, with special reference to Oncaeidae. J Plankton Res 30:529-550

Bone Q, Carre C, Ryan KP (2000) The endostyle and the feeding filter in salps (Tunicata). J Mar Biol UK 80:523-534

Boxshall GA, Halsey S (2004) An introduction to Copepod diversity. The Ray Society, London, p 966

Calbet A, Landry MR (1999) Mesozooplankton influences on the microbial food web: direct and indirect trophic interactions in the oligotrophic open ocean. Limnol Oceanogr 44:1370-1380

Calbet A, Landry MR, Scheinberg RD (2000) Copepod grazing in a subtropical bay: species-specific responses to a midsummer increase in nanoplankton standing stock. Mar Ecol Prog Ser 193:75-84

Casciotti KL, Trull TW, Glover DM, Davies D (2008) Constraints on nitrogen cycling at the subtropical North Pacific Station ALOHA from isotopic measurements of nitrate and particulate nitrogen. Deep Sea Res Part II 55:1661-1672

Chen Y, Mills S, Street J, Golan D, Post A, Jacobson M, Paytan A (2007) Estimates of atmospheric dry deposition and associated input of nutrients to Gulf of Aqaba seawater. J Geophys Res Atmosph 112(D4):D04309

Claessens M, Wickham SA, Post AF, Reuter M (2008) Ciliate community in the oligotrophic Gulf of Aqaba, Red Sea. Aquat Microb Ecol 53:181-190

Cornils A, Schnack-Schiel SB, Al-Najjar T, Badran MI, Rasheed M, Manasreh R, Richter C (2007a) The seasonal cycle of the epipelagic mesozooplankton in the northern Gulf of Aqaba (Red Sea). J Mar Syst 68:278-292

Cornils A, Schnack-Schiel SB, Boer M, Graeve M, Struck U, Al-Najjar T, Richter C (2007b) Feeding of Clausocalanids (Calanoida, Copepoda) on naturally occurring particles in the northern Gulf of Aqaba (Red Sea). Mar Biol 151:1261-1274

Dominguez A, Rosas J, Velasquez A, Cabrera T, Mata E (2007) Development, survival and growth of sea urchin Lytechinus variegatus (Lamarck, 1816) (Echinodermata : Echinoidea) fed on microalgae at two different salinities and temperatures. Rev Biol Mar Oceanogr 42:49-57

Dufresne A, Ostrowski M, Scanlan DJ, Garczarek L, Mazard S, Palenik BP, Paulsen IT, de Marsac NT, Wincker P, Dossat C, Ferriera S, Johnson J, Post AF, Hess WR, Partensky F (2008) Unraveling the genomic mosaic of a ubiquitous genus of marine cyanobacteria. Genome Biol 9(5):R90.6

Foster RA, Paytan A, Zehr JP (2009) Seasonality of $\mathrm{N}_{2}$ fixation and nifH gene diversity in the Gulf of Aqaba (Red Sea). Limnol Oceanogr 54:219-233

Fry B (2006) Stable isotope ecology. Springer, New York, p 308

Giesecke R, Gonzalez HE (2004) Mandible characteristics and allometric relations in copepods: a reliable method to estimate prey size and composition from mandible occurrence in predator guts. Revista Chilena De Historia Natural 77:607-616

Go YB, Oh BC, Terazaki M (1998) Feeding behavior of the poecilostomatoid copepods Oncaea spp. on chaetognaths. J Mar Syst 15:475-482

Gonzalez HE, Smetacek V (1994) The possible role of the cyclopoid copepod Oithona in retarding vertical flux of zooplankton fecal material. Mar Ecol Prog Ser 113:233-246

Gordon N, Angel DL, Neori A, Kress N, Kimor B (1994) Heterotrophic dinoflagellates with symbiontic cyanobacteria and nitrogen limitation in the Gulf of Aqaba. Mar Ecol Prog Ser 107:83-88

Hansen T, Sommer $\mathrm{U}$ (2007) Increasing the sensitivity of $\delta{ }^{13} \mathrm{C}$ and $\delta$ ${ }^{15} \mathrm{~N}$ abundances measurements by a high sensitivity elemental analyzer connected to an isotope ratio mass spectrometer. Rapid Comm Mass Spectr 21:314-318
Ho JS, Ohtsuka S, Nakadachi N (2006) A new family of poecilostomatoid copepods (Umazuracolidae) based on specimens parasitic on the black scraper (Thamnaconus modestus). Japan Zool Sci 23:483-496

Huys R, Boxshall GA (1991) Copepod evolution. The Ray Society, London, p 468

Kehayias G, Lykakis J, Fragopoulu N (1996) The diets of the chaetognaths Sagitta enflata, S. serratodentata atlantica and $S$. bipunctata at different seasons in eastern Mediterranean coastal waters. ICES J Mar Sci 53(5):837-846

Kettler GC, Martiny AC, Huang K, Zucker J, Coleman ML, Rodrigue S, Chen F, Lapidus A, Ferriera S, Johnson J, Steglich C, Church GM, Richardson P, Chisholm SW (2007) Patterns and implications of gene gain and loss in the evolution of Prochlorococcus. Plos Genetics 3:2515-2528

Kimor B, Golandsky B (1977) Microplankton of the Gulf of Eilat: aspects of seasonal and bathymetric distribution. Mar Biol 42:55-67

Kleppel GS (1993) On the diets of calanoid copepods. Mar Ecol Prog Ser 99:183-195

Kleppel GS, Frazel D, Pieper RE, Holliday DV (1988) Natural diets of zooplankton off southern California. Mar Ecol Prog Ser 49:231-241

Koski M, Moller EF, Maar M, Visser AW (2007) The fate of discarded appendicularian houses: degradation by the copepod, Microsetella norvegica, and other agents. J Plankton Res 29:641-654

Lindell D, Post AF (1995) Ultraphytoplankton succession is triggered by deep winter mixing in the Gulf of Aqaba (Eilat), Red-Sea. Limnol Oceanogr 40:1130-1141

Mackey KRM, Labiosa RG, Calhoun M, Street JH, Post AF, Paytan A (2007) Phosphorus availability, phytoplankton community dynamics, and taxon-specific phosphorus status in the Gulf of Aqaba, Red Sea. Limnol Oceanogr 52:873-885

Matthews B, Mazumder A (2003) Compositional and interlake variability of zooplankton affect baseline stable isotope signatures. Limnol Oceanogr 48:1977-1987

McClelland JW, Holl CM, Montoya JP (2003) Relating low delta ${ }^{15} \mathrm{~N}$ values of zooplankton to $\mathrm{N}_{2}$-fixation in the tropical North Atlantic: insights provided by stable isotope ratios of amino acids. Deep-Sea Res Part I 50:849-861

Meyer-Claeden O (2007) Vertikale und horizontale Verteilungsmuster der Zooplanktongemeinschaften am Senghor-Seeberg (Kapverdische Inseln). Diploma thesis, University of Kiel, Germany, pp 86

Mintenbeck K, Jacob U, Knust R, Arntz WE, Brey T (2007) Depthdependence in stable isotope ratio delta N-15 of benthic POM consumers: the role of particle dynamics and organism trophic guild. Deep-Sea Res Part I 54:1015-1023

Montoya JP, Horrigan SG, McCarthy JJ (1990) Natural abundance of $15 \mathrm{~N}$ in particulate nitrogen and zooplankton in the Chesapeake Bay. Mar. Ecol. Prog. Ser. 65:35-61

Montoya JP, Wiebe PH, McCarthy JJ (1992) Natural abundance of ${ }^{15} \mathrm{~N}$ in particulate nitrogen and zooplankton in the Gulf-Stream Region and Warm-Core Ring 86a. Deep-Sea Res Part A 39:S363-S392

Montoya JP, Carpenter EJ, Capone DG (2002) Nitrogen fixation and nitrogen isotope abundances in zooplankton of the oligotrophic North Atlantic. Limnol Oceanogr 47:1617-1628

Montoya JP, Holl CM, Zehr JP, Hansen A, Villareal TA, Capone DG (2004) High rates of $\mathrm{N}_{2}$ fixation by unicellular diazotrophs in the oligotrophic Pacific Ocean. Nature 430:1027-1031

Mullin MM, Rau GH, Eppley RW (1984) Stable nitrogen isotopes in zooplankton-some geographic and temporal variations in the North Pacific. Limnol Oceanogr 29:1267-1273 
Nakamura Y, Turner JT (1997) Predation and respiration by the small cyclopoid copepod Oithona similis: how important is feeding on ciliates and heterotrophic flagellates? Plankton Res 19:1275-1288

Paffenhoefer G-A (1993) On the ecology of marine cyclopoid copepods (Crustacea, Copepods). J Plankton Res 15(1):37-55

Post D (2002) Using stable isotopes to estimate trophic position: models, methods, and assumptions. Ecology 83:703-718

Post AF, Dedej Z, Gottlieb R, Li H, Thomas DN, El-Absawi M, El-Naggar A, El-Gharabawi M, Sommer U (2002) Spatial and temporal distribution of Trichodesmium spp. in the stratified Gulf of Aqaba, Red Sea. Mar Ecol Progr Ser 239:241-250

Saito H, Kiorboe T (2001) Feeding rates in the chaetognath Sagitta elegans: effects of prey size, prey swimming behaviour and small-scale turbulence. J Plankton Res 23:1385-1398

Scanlan DJ, Ostrowski M, Mazard S, Dufresne A, Garczarek L, Hess WR, Post AF, Hagemann M, Paulsen I, Partensky F (2009) Ecological genomics of marine picocyanobacteria. Microbiol Molecul Biol Rev 73:249-299

Sommer U, Berninger UG, Boettger-Schnack R, Cornils A, Hagen W, Hansen T, Al-Najjar T, Post AF, Schnack-Schiel SB, Stibor H, Stuebing D, Wickham S (2002) Grazing during early spring in the Gulf of Aqaba and the northern Red Sea. Mar Ecol Prog Ser 239:251-261

Terazaki M (1998) Life history, distribution, seasonal variability and feeding of the pelagic chaetognath Sagitta elegans in the Subarctic Pacific: a review. Plankton Biol Ecol 45:1-17

Turner JT (1986) Zooplankton feeding ecology: contents of fecal pellets of the cyclopoid copepods Oncaea venusta, Corycaeus amazonicus, Oithona plumifera and O. simplex from the northeastern Gulf of Mexico. Mar Ecol 28:9-302

Turner JT (2004) The importance of small planktonic copepods and their roles in pelagic marine food webs. Zool Stud 43(2):255266

Waite AM, Muhling BA, Holl CM, Beckley LE, Montoya JP, Strzelecki J, Thompson PA, Pesant S (2007) Food web structure in two counter-rotating eddies based on delta ${ }^{15} \mathrm{~N}$ and delta ${ }^{13} \mathrm{C}$ isotopic analyses. Deep-Sea Res Part II 54:1055-1075

Wankel SD, Chen Y, Kendall C, Post AF, Paytan A (2009) Sources of aerosol nitrate to the Gulf of Aqaba: evidence from $\delta^{15} \mathrm{~N}$ and $\delta^{18} \mathrm{O}$ of nitrate and trace metal chemistry. Mar Chem doi: 10.1016/j.marchem.2009.01.013(in press)

Webb EA, Ehrenreich IM, Brown SL, Valois FW, Waterbury JB (2009) Phenotypic and genotypic characterization of multiple strains of the diazotrophic cyanobacterium Crocosphaera watsonii isolated from the open ocean. Environ Microbiol 11:338-348

Wickstead JH (1962) Food and feeding of pelagic copepods. Proc Zool Soc Lond 139:545-555

Zehr JP, Waterbury JB, Turner PJ, Montoya JP, Omoregie E, Steward GF, Hansen A, Karl DM (2001) Unicellular cyanobacteria fix $\mathrm{N}_{2}$ in the subtropical North Pacific Ocean. Nature 412:635-638

Zehr JP, Bench SR, Carter BJ, Hewson I, Niazi F, Shi T, Tripp HJ, Affourtit JP (2008) Globally distributed uncultivated oceanic $\mathrm{N}_{2^{-}}$ fixing cyanobacteria lack oxygenic photosystem II. Science 322(5904):1110-1112 